\title{
A Review of Music Perception with Cochlear Implantation
}

\author{
Woojae $\mathrm{Han}^{1}$, Saea Kim ${ }^{2}$, Eunsung Lee ${ }^{2}$, and Jinsook Kim ${ }^{1}$ (iD \\ ${ }^{1}$ Division of Speech Pathology and Audiology, Research Institute of Audiology and Speech Pathology, College of Natural Sciences, \\ Hallym University, Chuncheon; and \\ ${ }^{2}$ Department of Speech Pathology and Audiology, Graduate School, Hallym University, Chuncheon, Korea
}

\section{인공와우를 이용한 음악지각에 대한 고찰}

한우재 $^{1} \cdot$ 김세아 ${ }^{2} \cdot$ 이은성 ${ }^{2} \cdot$ 김진숙 $^{1}$

한림대학교 자연과학대학 언어청각학부, 청각언어연구소, ${ }^{1}$ 한림대학교 일반대학원 언어병리청각학과 ${ }^{2}$

\author{
Received August 27, 2018 \\ Revised November 11, 2018 \\ Accepted December 4, 2018 \\ Address for correspondence \\ Jinsook Kim, PhD \\ Division of Speech Pathology and \\ Audiology, Research Institute of \\ Audiology and Speech Pathology, \\ College of Natural Sciences, \\ Hallym University, 8602 \\ Natural Sciences Building, \\ 1 Hallymdaehak-gil, Chuncheon \\ 24252 , Korea \\ Tel $+82-33-248-2213$ \\ Fax $+82-33-256-3420$ \\ E-mail jskim@hallym.ac.kr
}

With a high sound quality stimulated by the electrical device and a large inclusion in medical insurance, the number of cochlear implant recipients has been rapidly increased in Korea. Today, it is not surprising that early implanted young children with congenital deafness show a similar performance to their normal hearing peers in speech perception. However, the cochlear implant users still have a trouble to enjoy music. This review study aims to introduce briefly about acoustic components that required to perceive the music and understand a relationship between cochlear implantation and temporal fine structure. For the pediatric implant users who have less experience on acoustical sound features but are much familiar with the electrically stimulated sound, perceiving the music seems to be challengeable due to the lack of temporal fine resolution related to pitch and timbre among various components of music. Four representative test batteries for evaluating the recipients' ability of the music perception were mentioned and effective auditory music trainings were discussed with analysis of related investigations. Unlike hearing aids users who usually depend on fitting algorism for better music quality, the cochlear implant users need systematic training to improve their music perception ability. In conclusion, advancement of speech processing technology which can provide accurate information about the temporal fine structure of incoming music to the recipients needs to be developed. Also, a practical application of music training should be recommended as a part of auditory training for the cochlear implant users.

Korean J Otorhinolaryngol-Head Neck Surg 2019;62(4):207-15

Key Words Music perception · Cochlear implant · Pitch perception · Musical training.

\section{서 론}

1961년 Dr. William House가 단채널 인공와우 이식술에 성 공하면서 인공와우의 역사는 시작되었고, 3년 뒤인 1964년 미 국 스탠포드 대학의 Drs. Simmons와 White에 의해 6개 채

This is an Open Access article distributed under the terms of the Creative Commons Attribution Non-Commercial License (https://creativecommons.org/licenses/by-nc/4.0) which permits unrestricted non-commercial use, distribution, and reproduction in any medium, provided the original work is properly cited.
널의 인공와우를 환자들에게 이식하면서 임상적 적용의 가능 성이 확인되었다. ${ }^{1)}$ 한편, 이식기기 측면에서는 1972년 단채널 인공와우에 적용 가능한 어음처리기가 개발되었고, 1978년 10 개 채널의 인공와우를 이식하였을 때 전극의 위치에 따라 주 파수가 다르게 인식되는 현상을 연구로 증명하였다. ${ }^{1)}$ 이러한 의학 및 기술의 발전과 더불어, 미국 식품의약청(Food and Drug Administration)으로부터 1985년과 1990년에 성인과 아 동에 대한 인공와우의 이식이 차례로 승인받으면서 전세계적 
으로 이식술이 활성화되었고, 수술법, 매핑법, 재활법 등 인공 와우와 관련된 다양한 연구들이 많은 임상 전문가들에 의해 수행되었다. 2012년까지 전 세계적으로 약 32만 명의 청각 장애 인들이 인공와우 이식술을 받았으며, 국내에서는 1988년 처음 으로 인공와우 이식술이 성공한 이래 2016년까지 약 1만명의 청각장애인들이 이식술을 받은 것으로 추정된다. ${ }^{2}$ 국내에서 신생아청각선별 검사의 정착으로 선천적 난청으로 진단받은 영유아는 12 개월 전후로 인공와우의 조기 이식이 가능해졌 고, 2005년부터는 인공와우 이식 대상자에게 건강보험이 적용 되기 시작하여 2009년부터 그 적용 범위가 단이에서 양이로 확대되었다. 게다가, 2017년부터는 보험 적용 연령 기준을 기존 15 세에서 19세로 확대함에 따라 청소년들을 대상으로 실시한 이식 건수도 급증하였다. 또한 수명 연장으로 노년의 삶의 질 향상 측면에서도 노인성난청 환자들이 인공와우 이식을 희망 하는 경우가 꾸준히 증가하고 있다. 최근에는 스위스 베른 대 학에서 로봇을 도입하여 시행한 인공와우 이식술이 세계 최 초로 성공하면서 수술 중 내이 손상 가능성을 최소화하며 잔 존 청력을 보다 많이 보존할 수 있게 되어, 앞으로 인공와우 이식술은 더욱 발전될 것으로 기대된다. ${ }^{3)}$

일반적으로 인공와우 이식은 보청기의 이득만으로 의사소 통에 한계가 있는 고심도 난청의 환자들에게 소리를 제공한 다. Park 등 ${ }^{4}$ 의 연구에 따르면, 3.5 세 이전에 양이 인공와우 이식술을 받은 영유아들을 4년 이상 추적 및 관찰한 결과, $96.9 \%$ 의 높은 어음 인지 능력을 확인하였다. 또한 첫 인공와 우 이식을 7세 이전에 받고 반대쪽 귀에는 13세 이전에 이식 을 받은 경우, 약 $80 \%$ 정도의 어음 인지 능력을 나타내어 인 공와우의 조기 이식이 난청 아동의 의사소통능력에 상당한 개 선을 보여주는 것으로 보고되었다. ${ }^{4)}$ 그러나 이렇게 최신화된 인공와우도 여전히 한계를 갖고 있다. Nelson 등ㄱ은 조용한 상황과 소음 상황에서 정상 청력의 성인과 인공와우 착용자들 의 어음 인지 능력을 비교하였다. ${ }^{5)}$ 조용한 상황에서는 두 그룹 간 어음 인지 능력에서 큰 차이가 나타나지 않았으나, 소음 상 황에서는 두 그룹 간에 현저한 어음 인지 능력의 차이가 나타났 다. 구체적으로, 정상 청력의 그룹은 $-8 \mathrm{~dB}$ Signal-to-Noise Ratio(SNR)의 소음 상황에서도 변조된 주파수에 따라 70 $90 \%$ 의 어음 인지 수행력을 보였지만, 인공와우 착용 그룹은 $+16 \mathrm{~dB}$ SNR에서도 약 55 65\%의 저조한 어음 인지 수행력을 나타냈다. 즉, 정상 청력의 성인들은 배경 소음이 다소 큰 상 황에서도 우수한 어음 인지 능력을 보인 반면, 인공와우 착용 자들은 훨씬 적은 배경 소음의 제시만으로도 언어를 인지하 는 데 어려움을 나타내어 소음 환경에서의 어음인지 향상을 위한 기술적·재활적 개선이 필요한 것으로 나타났다. 더욱이, 음악을 듣고자 하는 착용자들의 증가하는 욕구를 충족시키기
에는 인공와우는 더 큰 제한점을 지니고 있다. ${ }^{6.7)}$ Mirza 등은 인공와우 착용자들의 증가하는 음악 청취에 대한 만족도를 조사하기 위해, 10 점 척도의 설문 문항을 활용하여 35 명의 심 도 난청자를 대상으로 인공와우의 이식 전과 후의 음악 청취 만족도를 측정하였다. 연구 결과, 이식 전에는 8.7점의 높은 만 족도를 보였으나 인공와우 이식 후에는 평균 2.6점으로 오히 려 낮은 만족도를 나타내어 연구자들은 인공와우의 이식이 착용자들의 음악 청취 만족에는 부정적인 영향을 미친다고 보고하였다. 즉, 전기적 자극을 통해 전달된 인공와우 착용은 음악에 대한 인지가 증가되지도 않을 뿐 아니라 오히려 음악 인지를 방해하는 것으로 나타났다. 이에 본 종설에서는 인공 와우를 통하여 착용자들이 음악을 어떻게 인지하는지에 대한 메커니즘을 이해해보고, 여러 선행 연구를 통해 보고된 인공 와우 착용자들의 음악지각에 대한 특징들을 분석하고자 한 다. 더불어, 음악 지각을 평가하는 검사도구의 구성 요소와 최 근 시행되고 있는 인공와우 착용자들을 위한 음악 훈련 등을 언급하면서 임상전문가로서 인공와우 착용자들의 음악 지각 능력을 향상시키기 위한 궁극적인 해결점도 함께 논의해 보 고자 한다.

\section{음악 지각의 음향학적 요소들}

인공와우 착용자들의 음악 지각을 이해하기에 앞서 먼저 음향학적 특색을 내포하고 있는 음악의 기본 요소들을 살펴 보면, 크게 리듬(rhythm), 고저(pitch), 화음(harmony), 음색 (timbre)으로 정리할 수 있다. 리듬이란 음악의 시간적 요소 와 관련이 있으며, 초 또는 분 단위로 나타나는 규칙적인 음의 범위이다. 고저는 음의 주파수를 주관적으로 나타내는 것으 로써, 음악의 음표를 의미하고 여러 개의 음표가 이루어져 멜 로디(melody)를 구성한다. 화음이란 음표가 연속적으로 구성 된 선율과는 달리, 음표 간 결합되어 이루어진 소리를 말한다. 즉, 소리가 중첩되어 나타나는 것으로, 단 3 화음, 장 3 화음 등 이 이에 해당한다. 마지막으로 음색은 음표를 표현하는 음의 질을 뜻하며, 같은 음표라도 음표를 표현하는 악기의 종류에 따라 그 음을 다르게 구별할 수 있게 하는 특성을 갖고 있다. ${ }^{8)}$ 간단히 음악의 음향적 특성과 연관 지어보면, 인공와우는 제 시된 소리의 정보에서 주로 고주파수 대역의 시간적 정보를 전달하기 때문에 인공와우 기기 내에 동일하게 고정된 배열로 구성된 전극을 통하여, 순간마다 제시되는 배음의 구성이 다 른 음악의 고저를 정확히 인지하기에는 어려움이 있다. Boëx 등은 한쪽 귀에 인공와우를 착용한 사람들을 대상으로 인공 와우 착용 귀에는 전기 자극을, 착용하지 않은 반대쪽 귀에는 음향적 자극을 제시하여 양이 간의 고저 차이를 비교하였 
다.' 연구 대상자가 양이를 통하여 들리는 자극음이 동일하다 고 판단하였을 때의 두음 간의 주파수는 약 두 옥타브 정도 의 수치 차이가 나타나 전기 자극과 음향 자극을 통한 고저 인 지 간에는 명확한 차이가 있음을 확인하였다. 즉, 현대의 기술 로 최신화된 인공와우의 이식으로도 음악의 음향적 신호가 정확히 전달되지 않았다. 또 다른 연구에서는 인공와우 착용 자 18 명에게 5 초 간격으로 멜로디가 다른 패턴 2 개와 리듬이 다른 패턴 2 개로 구성된 총 40 개의 자극음을 무작위로 제시 하여 인식된 두 개의 음의 동일 여부를 대상자에게 응답하도 록 요구하였다. 개인차는 있었지만 전반적으로 인공와우 착용 자들은 멜로디 패턴보다 리듬 패턴에서 더 높은 점수를 기록 하여, 앞선 연구와 동일하게 음악의 리듬 차이보다는 고저의 차이를 인지하는데 더 어려움을 나타내는 것으로 결론지었 다. ${ }^{10)}$ 그렇다면 인공와우 착용자들은 음의 고저, 멜로디, 음색 등을 인지하는데 어려움을 갖게 되는데, 이는 궁극적으로는 어떻게 저조한 음악 지각능력으로 이어지는 지 다음 단락에 서 좀 더 논의하였다.

\section{인공와우 이식과 시간적 미세구조}

일반적으로 음악이나 말소리와 같은 복합음은 느리게 변화 하는 진폭 정보인 포락(envelope, dashed line of Fig. 1)과 중 심 주파수에 가까울수록 빠르게 변화하는 진동 정보인 시간 적 미세구조(temporal fine structure, solid line of Fig. 1)로 분석되며, 이는 인공와우를 통해 발생되는 전기 신호의 원리 와도 밀접한 연관이 있다. ${ }^{11,12}$

청자들은 조용한 환경에서는 시간적 미세구조의 정보가 충분하지 않더라도 포락선 정보가 주어진다면 큰 어려움 없 이 어음을 인지할 수 있다. 그러나 소음 환경 속에서는 포락선 의 정보가 주어지더라도 시간적 미세구조에 대한 정보가 충 분치 않으면, 어음 인지에 어려움을 느낀다. ${ }^{13)}$ 이러한 원리는 감각 신경성의 난청 환자가 소음 환경 속에서 저조한 어음 인 지 능력을 보이는 현상에도 동일하게 적용된다. 즉, 난청 환자 들은 청력 손실로 인해 청각 필터가 넓어져서 시간적 미세구

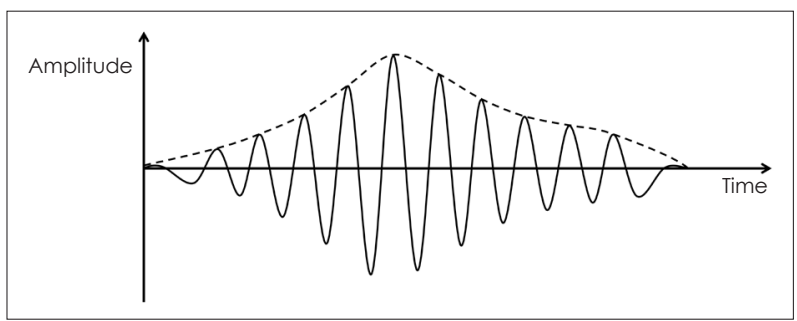

Fig. 1. Illustration of a simple sound waveform in terms of time and amplitude. A dashed line shows the envelopes of the waveform, whereas a solid line shows its temporal fine structure.
조 정보에 대한 인지에 어려움을 나타내며, 이에 배경 소음까 지 더해진다면 시간적 미세구조의 정보를 더 많이 놓치게 되 어 궁극적으로는 소음 하 어음 인지에 상당한 어려움을 보이 는 것으로 해석할 수 있다. ${ }^{11}$ 현재 적용되고 있는 인공와우 어 음처리기법은 외부로부터 입력되는 소리를 음향적으로 분석 하고 코딩화하여 전기적 신호로 전달하는데, 그 처리 과정에 서 포락선 정보는 대부분 전달될 수 있지만 시간적 미세구조 의 정보는 세밀하게 전달되지 못한다. ${ }^{12)}$ 이러한 기계적 한계는 앞서 언급한 대로 인공와우 착용자들에게 소음 하의 어음 인 지의 어려움은 물론 음악 지각에서도 부정적인 영향을 끼친 다. 따라서 향후, 보다 정교한 신호 처리 기술의 개발을 통해 시간적 미세구조 정보를 전달할 수 있는 기술적 보안 방안을 모색해야 하는 것이 인공와우 착용자들의 음악 지각의 개선 에 있어서 선행적 과제라 생각된다.

\section{음악 지각의 검사 도구}

현재 인공와우 착용자들에게 적용되고 있는 대표적인 음악 지각 검사 도구로는 Primary Measures of Music Audiation (PMMA), Montreal Battery for Evaluation of Amusia Musical sounds in Cochlear Implants(Mu.S.I.C), University of Washington Clinical Assessment of Music Perception(UWCAMP), Music in Children with Cochlear Implants(MCCI) 등이 있다.

먼저, PMMA는 1979년 Gordon ${ }^{14}$ 에 의해 개발되어 현재 가 장 널리 사용되고 있는 표준화된 음악 적성 검사이다. 음의 고 저와 리듬 검사 각 40 문항씩 총 80 문항으로 구성되어 있다. 하위 검사 항목에 따라 제시된 두 개의 음이 같은지 혹은 다 른지 여부를 평가하며, 특히 인공와우 착용 아동의 음악 지각 평가에 유용한 검사 방법으로 평가받고 있다. ${ }^{14)}$ 두 번째 도구 인 Mu.S.I.C ${ }^{15)}$ 은 리듬, 고저, 멜로디, 코드, 악기의 수, 악기명 에 관하여 음악 인지를 확인하는 6 가지 검사들과 이에 관련 된 불협화음 및 감정 여부를 확인하는 검사들로 구성되어 있 다. Mu.S.I.C에서는 영국의 The Royal Scottish Academy of Music and Drama에서 실제로 녹음한 2,800개의 악기 소리 음원을 대상자의 쾌적역치강도(most comfortable level)에서 제시하고, 각 검사 별로 제시된 음원들 간의 차이를 인지할 수 있는지 평가한다. ${ }^{15)}$ 세 번째 도구인 UW-CAMP ${ }^{16)}$ 는 환자의 음악 지각 정도를 정량적으로 평가하여 그 결과를 임상 현장 에서 실용화하기 위한 목적으로 고안되었다. 환자 스스로 컴 퓨터를 사용하여 음의 고저, 멜로디, 음색으로 구성된 세 가지 하위 검사를 평가하도록 구성되었다. ${ }^{16)}$ 마지막으로 가장 최근 에 개발된 $\mathrm{MCCI}^{17)}$ 는 리듬, 고저, 멜로디, 화음, 음색의 5 가지 
음악 지각 검사로 구성되어 있다. 대상자가 용이하게 사용할 수 있도록 제작되었고, 특히 음악 지각 능력을 평가하는데 짧 은 검사 시간이 소요되어 9세 미만의 인공와우 착용 유소아 들에게 사용할 수 있는 장점이 있다. ${ }^{17)}$ 각 검사의 세부적인 구 성 및 특징들을 Table 1에 간략하게 요약하였다.

\section{인공와우를 통한 음악 지각}

\section{In adult $\mathrm{CI}$ users}

잘 알려진 대로, 후천적 난청 성인들은 인공와우 이식 후 조용한 상황에서 우수한 어음 인지도를 나타낸다. ${ }^{18)}$ 이를 음 악 지각 능력과 연결해보면 인공와우의 자극 패턴은 음악의 기본적인 리듬을 정확히 인지할 수 있도록 충분한 정보를 제 공한다. ${ }^{19)}$ 예를 들어, PMMA를 이용한 Looi 등 ${ }^{20}$ 의 연구에서 는 보청기 착용 그룹과 인공와우 착용 그룹에게 한 쌍의 연속 된 음계를 들려주고 리듬의 동일 여부를 물어 보았을 때, 두 그룹 간 수행력에서 유의미한 차이가 나타나지 않았다. ${ }^{20)}$ 동 일한 실험 조건으로 Looi 등른 보청기 착용 경험이 있는 고심도 난청의 인공와우 이식 환자들을 대상으로 이식 전과 후의 PMMA 검사를 실시하였고, 두 조건 모두 95\%의 동일 한 수행력을 보여 유의미한 차이가 없었다. ${ }^{21)}$ 후천적 난청인의 경우에도, 보청기와 인공와우 간 청각보조기기의 비교 뿐 아 니라 인공와우 이식 전과 후의 시간차의 비교에서도 뚜렷한 차이가 나타나지 않아 리듬 패턴은 난청 성인들에게 어렵지 않게 인지된다고 결론 지을 수 있겠다.

이와 반대로, 인공와우 착용 성인의 음의 고저 인지는 정상 청력의 성인에 비해 매우 저조하게 보고되고 있다. ${ }^{20)}$ 이는 음 의 고저에 따라 의미나 어조가 변하는 성조 언어(예를 들어,
만다린어)의 어음 인지 및 의미 전달에도 큰 어려움으로 이어 진다. ${ }^{19)}$ 인공와우 착용자를 대상으로 실시한 음악 인지 연구 들에서는 주로 대중화된 노래에서 추출한 멜로디가 자주 사 용되었다. 검사에서는 익숙한 음악의 제목이 적힌 목록을 연 구 대상자에게 제공하고, 각각의 멜로디를 듣고 재생되고 있는 음악의 이름을 맞추도록 요청하였다. 그 중 리듬, 가사(lyrics), 화음의 유무는 청취 환경에 따라 다른 양상을 보였는데, Galvin 등 22 의 연구는 유사한 청취 환경에서 리듬 패턴을 추 가하였을 때 수행력이 $32 \%$ 까지 향상되었고, ${ }^{22)} \mathrm{El} \mathrm{Fata} \mathrm{등}{ }^{23}$ 의 연구에서는 멜로디 인지에 있어 리듬과 화음만을 제시하였을 때보다 추가적으로 가사를 제시하였을 때 인공와우 착용자들 의 음악 지각 수행력이 약 $41 \%$ 정도 향상되었다. ${ }^{23}$ 즉, 멜로디 인지에 있어서 리듬, 가사, 화음과 같은 추가적인 청취 환경에 따라 인공와우 착용자들은 정확한 음의 고저 정보를 인식하 게 되어 더 우수한 음악 지각 수행력을 보였다. ${ }^{716)}$

\section{In pediatric $\mathrm{CI}$ users}

대부분의 인공와우 이식 아동은 출생 시 농이거나 매우 큰 청력 손실을 지녔을 가능성이 높기 때문에, 성인 이식자들보 다는 이식 전 청각적 노출 경험이 훨씬 적다. 따라서 인공와우 착용 아동은 음악에 대한 인지를 기기에 의해 들려져오는 소 리에 따라 상상할 수밖에 없고, 이는 음악 인지 능력에 부정적 인 영향을 끼치게 된다. 선행 연구에 따르면, 인공와우 착용 성인과 아동을 대상으로 동일한 청취 조건에서 멜로디 지각 평가를 진행하였을 때, 성인은 75 77\%의 중간 이상의 수행력 을 보인 반면, 아동은 약 35 65\%의 다소 낮은 수행력을 보였 다. ${ }^{23,24)}$ 게다가, 인공와우 착용 아동은 인공와우의 전기적 자 극을 통해서만 소리를 경험하였기 때문에, 수술 전 자연음을

Table 1. Summary of four test batteries developed for evaluating music perception ability of the cochlear implant recipients

\begin{tabular}{|c|c|c|c|}
\hline Name & Developer & Contents & Characteristics \\
\hline $\begin{array}{l}\text { Primary Measures of } \\
\text { Music Audiation for } \\
\text { children }\end{array}$ & Gordon $(1979)^{14)}$ & $\begin{array}{l}\text { - Two subtests having (1) } 40 \text { pairs of } \\
\text { simple rhythms, and (2) } 40 \text { pairs of } \\
\text { 2-, 3-, 4-, or 5-tone sequences }\end{array}$ & $\begin{array}{l}\text { - About } 40 \text { minutes for test duration } \\
\text { - Simple instruction asking whether the } \\
\text { sequence in each pair is same or } \\
\text { different }\end{array}$ \\
\hline $\begin{array}{l}\text { Musical sounds in } \\
\text { cochlear implants } \\
\text { perception test }\end{array}$ & $\begin{array}{l}\text { Fitzgerald, et al. } \\
(2006)^{15)}\end{array}$ & $\begin{array}{l}\text { - Six objective subtests as (1) rhythm, } \\
\text { (2) pitch, (3) melody, (4) chords, } \\
\text { (5) number of instruments, and } \\
\text { (6) a sort of instrument } \\
\text { - Two subjective subtests with } \\
\text { (1) dissonance and (2) emotion }\end{array}$ & $\begin{array}{l}\text { - Less than } 90 \text { and } 70 \text { minutes test } \\
\text { durations for } \mathrm{Cl} \text { users and normal } \\
\text { hearing listeners, respectively } \\
\text { - Can assess music perception using } \\
\text { different languages } \\
\text { - Sensitive to challenges consisting } \\
\text { of various subtests }\end{array}$ \\
\hline $\begin{array}{l}\text { University of Washington's } \\
\text { Clinical Assessment of } \\
\text { Music Perception }\end{array}$ & $\begin{array}{l}\text { Kang, et al. } \\
(2009)^{16)}\end{array}$ & $\begin{array}{l}\text { - Three subtests of (1) pitch direction } \\
\text { discrimination, (2) melody identification, } \\
\text { and (3) timbre identification }\end{array}$ & $\begin{array}{l}\text { - Less than } 45 \text { minutes of test duration } \\
\text { - Self-evaluation with high efficiency as } \\
\text { computerized test format }\end{array}$ \\
\hline $\begin{array}{l}\text { Music in Children with } \\
\text { Cochlear Implants }\end{array}$ & $\begin{array}{l}\text { Roy, et al. } \\
(2014)^{17)}\end{array}$ & $\begin{array}{l}\text { - Five subtests, namely (1) rhythm, } \\
\text { (2) pitch, (3) melody, (4) harmony, and } \\
\text { (5) timbre perception }\end{array}$ & $\begin{array}{l}\text { - Less than } 45 \text { minutes test duration } \\
\text { - Easy instruction with user friendly format } \\
\text { - Same/different task }\end{array}$ \\
\hline
\end{tabular}


경험한 성인 인공와우 착용자에 비해 기계음에 더 쉽게 적응 할 뿐만 아니라, 환경적으로도 성인에 비해 인공와우 착용 후 청능 훈련에 참여할 기회가 높아 기계음에 보다 빠르게 적응 한다. ${ }^{19)}$ 이처럼 전기적 소리 자극에 자연스럽게 노출되는 환경 이 우세한 인공와우 착용 아동은 리듬 인지의 수행력에서 정 상 청력의 아동과 유의미한 차이를 보이지 않지만, 음의 고저 인지에 있어서는 정상 청력을 지닌 아동의 절반 수준의 수행 능력을 나타냈다. ${ }^{25)}$ 몇몇 연구에서는 노래 가사나 리듬 패턴과 같은 청각적 단서를 함께 제시하였을 때 인공와우 착용 성인 과 유사하게 인공와우 아동들의 멜로디 인지 역시 향상될 수 있음을 보고하여, 음악 지각 훈련 시 가사와 리듬의 동반이 효 율적으로 적용될 수 있음을 강하게 시사하였다. ${ }^{24)}$

\section{Comparison with hearing aids(HA) users as musical sound quality}

인공와우를 이식할 정도로 청력 손실이 심하지 않은 난청 인들은 주로 보청기를 통해 소리의 증폭을 얻게 된다. 일반적 으로 보청기는 어음 주파수대역인 200 5000 Hz의 주파수 를 선별적으로 증폭시켜 착용자들이 대화음을 잘 이해할 수 있도록 돕고 있지만, 그 외의 주파수 대역을 포함하는 음들은 지각하기 어려운 단점이 있다. 오래 전 시도된 Franks ${ }^{26}$ 의 연 구에서는 보청기 착용자들에게 $200 \mathrm{~Hz}$ 이하의 주파수를 추 가적으로 증폭하였을 때 음악을 더 잘 듣는다는 결과를 얻었 지만, $4000 \mathrm{~Hz}$ 이상의 주파수 대역을 증폭하였을 때는 음악 청취에 대한 선호도가 보청기 착용자마다 상이하게 나타났다 고 보고하였다. 따라서 연구자는 보청기를 통한 음악적 지각도 는 보청기의 피팅 방식에 따라 달라질 수 있음을 시사하였다. ${ }^{26)}$

그렇다면, 인공와우 착용자들의 음악적 지각에 대한 향상 혹은 변화는 어떻게 나타날까? 앞서 언급한 Mirza 등의 의 연구 와 달리, 2000년에 시도된 Gffeller 등 ${ }^{27}$ 의 연구에서는 인공 와우 착용 기간이 최소 12 개월 이상인 후천적 농이었던 이식 자들을 대상으로 기존의 Iowa Musical Background Questionnaire에 음악 청취의 즐거움과 음질에 영향을 미치는 환 경적 요소에 대한 질문들을 추가하여 총 21 개의 질문으로 새 로이 구성된 확장판 설문지를 적용한 결과, 보청기 착용 시 보 다 인공와우 착용 후 음악에 대한 만족도가 대체로 높은 편으 로 나타났다. ${ }^{27)}$ 또한 보청기와 인공와우에 따른 음악 인지 능 력을 비교하기 위하여 Looi 등 ${ }^{28)}$ 은 보청기 착용자와 인공와 우 착용자의 음악인지 능력을 솔로 악기, 오케스트라와 함께 연주된 악기, 앙상블의 자극음으로 구분하여 연구하였다. 또 한 연구대상자로 보청기를 착용하고 있으며 인공와우 수술 예정인 사람들도 포함하였다. 결론적으로 인공와우를 착용한 대상자들은 모든 검사에서 보청기를 착용한 대상자보다 높은
정답율을 보였으며, 이식 대상자들에서도 인공와우 수술 후 의 음악인지 능력이 수술 전 보청기를 착용하였을 때보다 높 게 나타났다. ${ }^{28)}$ Sucher와 $\mathrm{McDermott}{ }^{29}$ 의 연구에서는 인공와 우와 보청기를 양이에 각각 착용한 환자들을 인공와우만 착 용, 보청기만 착용, 인공와우와 보청기 모두 착용의 세 가지의 조건에서 16 개의 음악 소리를 구분하는 검사를 실시하였다. 검사는 대상자가 음악을 들었을 때 16 개 중 어떤 음악을 들었 는지 맞추는 방식으로 진행되었으며, 10점 척도로 대상자의 음악 인지 정도를 파악하였다. 음악 인지는 보청기 혹은 인공 와우만 착용하였을 때보다 인공와우와 보청기를 함께 착용하 였을 때 더 좋은 결과를 보여주었다. ${ }^{29)}$

위의 연구 결과를 종합해보면, 인공와우의 이식 후 착용자 들의 음악 지각이 향상된다고 예견할 수 있다. 또한 인공와우 착용자들의 음악 지각 능력은 착용하고 있는 인공와우의 매 핑보다는 음악훈련의 기간에 따라 음악지각능력이 좌우되는 것으로 나타났다. ${ }^{30}$ 그러나 여전히 연구들마다 상이한 결과를 보고하고 있다. 따라서 2012년 Looi 등 ${ }^{31)}$ 의 연구에서는 인공 와우 착용자가 느끼는 음질을 음색과 visual analogue scale 을 사용하여 음악 청취의 즐거움에 대한 정도를 음악 훈련 전 과 후로 비교해 보았다. 연구 결과, 음색 확인 검사에서는 훈련 전과 후에 유의미한 차이가 나타나지 않았지만, visual analogue scale을 통해 대상자들이 보고한 음악 청취의 즐거움 은 음악 훈련 후에 뚜렷이 향상되어 인공와우 착용자들에게 음악 훈련이 효율적으로 음악을 즐길 수 있도록 하는 필수 요 소임을 시사하였다. ${ }^{31)}$ 그렇다면, 인공와우 착용자들에게 적용 할 효율적인 음악 훈련은 무엇이 있을 지 다음 단락에서 좀 더 논의해 보자.

\section{음악 지각의 향상을 위한 효율적인 청능훈련}

난청인들은 인공와우 착용을 통해 말 인지능력의 향상 뿐 만 아니라 생활의 질을 높여줄 수 있도록 음악 지각 또한 향상 되어야 한다. 인공와우 착용자들에게 시도되고 있는 음악 훈 련은 다양하지만, 음악 지각 훈련의 효과 검증을 위한 연구들 은 아직 진행 단계에 있다. 아동들을 대상으로 음악 지각훈련 을 적용한 연구들은 주로 음의 고저를 인지하는 것을 목적으 로 한다. 예를 들어, Chen 등이은 심도 난청의 인공와우 착용 아동 27명을 모집하여 그 중 13명에게 3 36개월의 음악 훈련 을 실시하였다. 음악 훈련은 스코어 리딩, 듣기, 연주하기, 노래 부르기로 구성되었고, 훈련에 대한 성과를 확인하기 위해 음 의 고저 인지 검사를 실시하였다. 2 개의 서로 다른 피아노 소 리(첫 음은 피아노 $\mathrm{A} \sim \mathrm{G}$ 음 중 하나를, 두 번째 음은 피아노 $\mathrm{C}$ 
Table 2. Summary of music training studies for $\mathrm{Cl}$ recipients

\begin{tabular}{|c|c|c|c|}
\hline Study & Participants & Training methods & Results \\
\hline $\begin{array}{l}\text { Chen, et al. } \\
(2010)^{30)}\end{array}$ & $\begin{array}{l}27 \mathrm{Cl} \text { children } \\
\text { (congenital/prelingual deafness) }\end{array}$ & - Pitch perception training using piano & $\begin{array}{l}\text { - Performance of pitch perception } \\
\text { was higher depending longer } \\
\text { duration of music training. }\end{array}$ \\
\hline $\begin{array}{l}\text { Gfeller, et al. } \\
(2002)^{32)}\end{array}$ & $\begin{array}{l}24 \mathrm{Cl} \text { adults } \\
\text { (postlingual deafness) }\end{array}$ & $\begin{array}{l}\text {-While consisting of } 48 \text { lessons via } \\
\text { computer, timbre perception } \\
\text { training using four familiar musical } \\
\text { instruments such as strings, brass, } \\
\text { pitched percussion, and wood-winds }\end{array}$ & $\begin{array}{l}\text { - Compared scores of pre-training } \\
\text { and post-training showed enhanced } \\
\text { timbre perception performance. } \\
\text { - There was a similar result in the timbre } \\
\text { quality. }\end{array}$ \\
\hline $\begin{array}{l}\text { Looi, et al. } \\
(2012)^{33)}\end{array}$ & $\begin{array}{l}18 \mathrm{Cl} \text { adults \& } 13 \mathrm{HA} \text { adults } \\
\text { ( } \mathrm{Cl} \text { or } \mathrm{HA} \text { experienced users for } \\
\text { more than } 6 \text { months) }\end{array}$ & $\begin{array}{l}\text { - Five modules with teaching phase, } \\
\text { training phase, and self-testing phase } \\
\text { applying stimuli with instrument, } \\
\text { vocalist, and ensemble. }\end{array}$ & $\begin{array}{l}\text { - After the training, } \mathrm{Cl} \text { and HA users' } \\
\text { responses changed to be positive } \\
\text { and their subjective ratings of music } \\
\text { perception skills were improved. } \\
\text { - However, there was no significant } \\
\text { improvement in timbre perception } \\
\text { or pitch ranking. }\end{array}$ \\
\hline
\end{tabular}

Cl: cochlear implant, HA: hearing aid

또는 $\mathrm{B}$ 음)를 대상 아동에게 들려주고 들은 2 개의 소리에 대 한 일치 여부를 답하도록 지시하였다. 수집된 데이터는 인공 와우 기기, 성별, 훈련기간, 인공와우 착용기간을 기준으로 분석되었고, 착용 아동의 연령이 6세 미만인 경우 음악 훈련 기간이 길수록 음의 고저 인지 검사 결과가 높게 나타났다. 또 한 인공와우를 18 개월 이상 착용한 아동들의 경우 음악 훈련 기간이 길수록 음의 고저 인지 능력이 향상되었다. ${ }^{30)} \mathrm{Gfeller}$ 등 ${ }^{22)}$ 은 언어습득 후 농인 24명의 인공와우를 착용한 성인을 대상으로 음악 훈련을 진행하였다. 음악 지각을 목표로 개발 된 음악훈련프로그램은 16 개의 악기를 사용하여 12 주 동안 진행하였다. 음악 훈련의 효과를 확인하기 위해서 음색 인지 검사를 실시하였고, 제시되는 16 개의 악기 음을 듣고 화면에 나타난 16 개의 악기 사진 중 대상자가 들었던 음과 동일한 악 기 그림을 체크하도록 요구하였다. 음악 훈련 전과 비교하였을 때, 연구대상자들은 훈련 후 음색 인지 검사에서 통계적으로 유의하게 더 높은 점수를 나타내어 훈련 효과를 확인하였다. ${ }^{32)}$

음악 훈련이 음악지각능력을 향상시킬 수 있다는 사실은 Looi 등 ${ }^{31}$ 의 연구에서 한번 더 증명되었다. 인공와우 착용자 18 명과 보청기 착용자 13 명을 대상으로 음악 훈련 여부에 따 른 음악 청취 선호도와 훈련 전·후의 음악 인지 능력을 비교 한 결과이다. 구체적인 연구는 악기, 보컬리스트, 앙상블의 세 종류의 음원을 제시하고, 총 5 개의 모듈로 구성된 훈련 프 로그램으로. 1 4번의 모듈은 음악 듣기 훈련을 수행하도록 구 성하고 5번 모듈은 자가 훈련할 수 있도록 하였다. 그 중 1 3 번 모듈은 악기, 보컬리스트, 앙상블 등의 음악 종류에 대한 훈련할 수 있고 4번 모듈은 1 3번까지의 훈련을 합쳐 난이도 를 향상시킨 음악 훈련프로그램이다. 모듈을 진행하는 동안 대상자는 틀린 경우, 본인이 정답이라고 간주했던 음원과 실
제로 제시된 음원을 비교할 수 있도록 하고 이를 반복적으로 듣고 스스로 훈련할 수 있도록 하였다. 이러한 방법으로 대상 자들은 제시되는 음원들을 비교해가며 음원들의 차이를 인지 할 수 있고, 진행되었던 음악 훈련 프로그램에 대한 점수들을 스스로 조회하여 자가 점검하며 스스로 듣는 방법을 개선할 수 있도록 하였다. 또한 훈련 시간, 훈련 날짜 등의 구체적인 정 보도 스스로 확인할 수 있도록 하여 자기 추적이 가능하도록 하였다. 음악 훈련 프로그램에서 사용한 음원과 중복되지를 않도록 music test battery를 사용하여 음악 인지 훈련 후 검 사를 실시하여 음악 훈련을 받은 두 그룹 모두에서 음악 지각 능력이 향상된 것을 확인하였다. ${ }^{31)}$ 위의 3가지 음악 훈련 연구 에 관하여 Table 2에 좀 더 자세히 정리하였다.

\section{결 론}

인공와우는 짧은 역사에 비해 급속한 기술의 진보에 따라 많은 발전을 보여주었고, 전 세계적으로 왕성하고 다양한 연 구들이 진행됨에 따라 인공와우 이식을 통해 많은 고심도의 난청인들이 소리를 들을 수 있게 되었다. 특히 유소아의 경우, 조기 인공와우 수술을 하고 체계적이고 적절한 청능 훈련으로 정상 청력을 지닌 아동의 어음 인지 능력과 유사한 결과를 보 이기도 하였다. ${ }^{4}$ 그러나 여러 연구에서 지적했듯이, 인공와우 대상자는 여전히 소음 하의 어음 인지에서 상당한 어려움을 호 소하고 있으며, 음악 지각에 있어서도 만족도가 매우 낮다. 본 종설에서는 음악의 음향학적 기본 요소인 음의 고저, 리듬, 음 색을 중심으로 음악 지각에 있어서 인공와우 착용자들의 인 지 능력을 분석하고 개선 방향을 모색하였다. 일반적으로 리듬의 인지에 있어서는 인공와우 착용 아동과 성인 모두 정 
상 청력인과 유사한 우수한 수행력을 보이지만, 음의 고저와 음색에 있어서는 정상 청력인에 비해 매우 저조하였다.21) 이는 인공와우 착용자가 조용한 상황에서는 어음을 잘 인지하는 반면, 소음 하 어음 인지에 어려움을 보이는 현상과 유사한 현상으로 나타났다. 즉, 음의 고저의 인지와 소음 하 어음 인 지에 필수적인 시간적 미세구조의 정보가 인공와우 착용자에 게 충분하게 제공되지 않기 때문이다. ${ }^{11)}$ 보다 구체적으로, 성 인과 아동의 인공와우 착용자들을 비교해 보았을 때 두 그룹 모두 음의 고저와 음색에 있어서는 저조한 수행력을 보였지 만, 아동의 경우 음의 고저 인지에 있어 리듬, 가사, 화음 등 의 추가적 제공을 통해 단서가 많은 청취 환경에서는 대체로 더 우수한 수행력을 나타냈다. ${ }^{7}$ 특히 선천적 난청 아동의 경 우, 인공와우 이식 전 청각적 경험이 전무하기 때문에 인공와 우를 통한 기계음에 좀 더 잘 적응할 수 있는 것으로 알려져 있지만, ${ }^{7}$ 오히려 기계음에만 익숙하기 때문에 음악의 음향적 정보, 특히 음의 고저를 정확하게 인식하는 데에는 많은 어려 움을 보이고 이러한 현상은 노래를 부를 때도 음의 고저 인지 가 매우 저조하게 나타났다. ${ }^{25)}$ 이와 반대로 일부 연구에서는 인공와우 착용자들의 음악 지각 능력이 보청기를 착용하는 사람들보다 높다는 결과가 보고되었다. ${ }^{30}$ 즉, 보장구(보청기, 인공와우)를 착용했을 때 음악 지각 능력은 향상되나 그 정도 는 재활 기간 및 보장구 조절 방법에 따라 다르게 나타났다.

본 종설에서 살펴본 인공와우 착용자들의 음악 지각을 평 가하는 대표적인 검사 도구로는 PMMA, Mu.S.I.C, UWCAMP, MCCI의 4가지가 있으며 평가의 목적에 따라 달리 사 용되고 있다. 그 중에서도 PMMA는 가장 대표적인 검사로써 음의 고저와 리듬에 대하여 평가할 수 있고, Mu.S.I.C ${ }^{15)}$ 은 객 관적, 주관적 검사로 나누어 평가할 수 있는 검사이다. UW$\mathrm{CAMP}^{16)}$ 는 음의 고저, 리듬, 멜로디, 화음, 음색에 대하여 평 가할 수 있으며 최근 한국어로도 번역되어(K-CAMP) 국내 임상에서도 적용되고 있다. ${ }^{33)} \mathrm{MCCI}^{17)}$ 는 음의 고저, 리듬, 멜 로디, 화음, 음색에 대하여 평가할 수 있다. 그러나 많은 수의 인공와우 이식 건수에 비해 국내에서는 아직 인공와우 착용 자들의 음악 지각과 관련된 연구가 활발하게 이루어지지 않 고 있다. 더욱이 인공와우 이식자들의 음악 지각에 대해 올바 르고 객관적인 검사를 수행하기 위해서는 국내에서도 추후 문화적·정서적으로 국내에서 사용이 적절한 신뢰도와 타당 도가 검증된 검사 도구들이 개발되고 적용되어야 하겠다. 인 공와우 착용자들의 음악 훈련에 대한 연구는 주로 음의 고저 를 인지하는 것을 목적으로 국내외에서 계속 진행 중에 있으 며 아동의 경우 훈련기간이 길수록 음악인지능력이 증가한다 고 보고되었다. 국내에서는 음악 훈련과 유사한 음악 치료도 난청인들을 대상으로 제공되고 있다. 주로 음악치료사들이 제
공하는 음악 치료는 청각 센터나 음악치료센터에서도 시행되 고 있으나, 인공와우 착용의 효율성을 높이기 위해서는 청각 전문가가 음악 훈련을 동반한 청능 훈련을 제공해야 할 것으 로 생각된다. ${ }^{34)}$ 앞서 언급한 대로 현재 인공와우 기술은 음악 인지에 있어 리듬에 대해서는 충분한 정보를 제공하고 있으 나, 음의 고저와 음색에 대해서는 충분한 정보를 제공하는데 부족하며, 이를 해결하기 위하여 시간적 미세 구조 정보의 분 석 기술을 제시하는 데는 한계가 있다. 그럼에도 선행 연구들 에 따르면, 훈련 전과 후의 결과를 비교하였을 때, 훈련에 따 라 고저와 음색의 인지가 다소 향상되었고, 부차적으로 어음 인지력과 작업기억력도 향상됨을 증명하였다. ${ }^{34)}$ 결론적으로 보다 다양한 신호처리 기술, 특히 시간적 미세구조 정보를 분 석할 수 있는 기술 개발을 기대하며, 현재로는 체계화된 청능 재활 속에 음악 훈련으로 현재 기술로 구현 가능한 소리를 착 용자들이 더 잘 들을 수 있는 음악 훈련 방법을 많은 전문가 와 임상가들이 개발하고 적용하여 인공와우 착용자도 음악을 즐기고 삶의 질을 향상할 수 있게 되기를 바란다.

\section{Acknowledgments}

This work was supported by the Ministry of Education of the Republic of Korea and the National Research Foundation of Korea (NRF-2018S1A3A2074932).

\section{ORCID}

Jinsook Kim

https://orcid.org/0000-0003-3440-2393

\section{REFERENCES}

1) Clark GM, Tong YC, Black R, Forster IC, Patrick JF, Dewhurst DJ. A multiple electrode cochlear implant. J Laryngol Otol 1977;91(11): 935-45.

2) Lee KS. Soree ear clinic is responsible for one out of four cases of cochlear implant in Korea. [cited 2016 Nov 15]. Available from: URL: http://news.kmib.co.kr/article/print.asp?arcid=0923642008.

3) Bell B, Stieger C, Gerber N, Arnold A, Nauer C, Hamacher V, et al. A self-developed and constructed robot for minimally invasive cochlear implantation. Acta Otolaryngol 2012;132(4):355-60.

4) Park HJ, Lee JY, Yang CJ, Park JW, Kang BC, Kang WS, et al. What is the sensitive period to initiate auditory stimulation for the second ear in sequential cochlear implantation? Otol Neurotol 39(2):177-83.

5) Nelson PB, Jin SH, Carney AE, Nelson DA. Understanding speech in modulated interference: cochlear implant users and normalhearing listeners. J Acoust Soc Am 2003;113(2):961-8.

6) Mirza S, Douglas SA, Lindsey P, Hildreth T, Hawthorne M. Appreciation of music in adult patients with cochlear implants: a patient questionnaire. Cochlear Implants Int 2003;4(2):85-95.

7) McDermott HJ. Music perception with cochlear implants: a review. Trends Amplif 2004;8(2):49-82.

8) Limb CJ. Cochlear implant-mediated perception of music. Curr Opin Otolaryngol Head Neck Surg 2006;14(5):337-40.

9) Boëx C, Baud L, Cosendai G, Sigrist A, Kós MI, Pelizzone M. Acoustic to electric pitch comparisons in cochlear implant subjects with residual hearing. J Assoc Res Otolaryngol 2006:7(2);110-24.

10) Gfeller K, Lansing CR. Melodic, rhythmic, and timbral perception of adult cochlear implant users. J Speech Hear Res 1991:34(4):916- 
20.

11) Moore BC. The role of temporal fine structure processing in pitch perception, masking, and speech perception for normal-hearing and hearing-impaired people. J Assoc Res Otolaryngol 2008;9(4):399406.

12) Chang YS, Moon IJ. Definition and clinical implication of temporal fine structure. Korean J Otorhinolaryngol-Head Neck Surg 2018; 61(1):1-8.

13) Hopkins K, Moore BC, Stone MA. Effects of moderate cochlear hearing loss on the ability to benefit from temporal fine structure information in speech. J Acoust Soc Am 2008;123(2):1140-53.

14) Gordon EE. Primary measures of music audiation. Chicago: GIA Publications, Inc.;1979. p.42-9.

15) Fitzgerald D, Fitzgerald H, Brockmeier SJ, Searle O, Grebenev L, Nopp P. Musical Sounds in Cochlear Implants (MuSIC) Test. Innsbruck: MED-EL;2006.

16) Kang R, Nimmons GL, Drennan W, Longnion J, Ruffin C, Nie K, et al. Development and validation of the University of Washington Clinical Assessment of Music Perception test. Ear Hear 2009;30(4): 411-8.

17) Roy AT, Scattergood-Keepper L, Carver C, Jiradejvong P, Butler C, Limb CJ. Evaluation of a test battery to assess perception of music in children with cochlear implants. JAMA Otolaryngol Head Neck Surg 2014;140(6):540-7.

18) Helms J, Weichbold V, Baumann U, von Specht H, Schön F, Müller $\mathrm{J}$, et al. Analysis of ceiling effects occurring with speech recognition tests in adult cochlear-implanted patients. ORL J Otorhinolaryngol Relat Spec 2004;66(3):130-5.

19) Zeng FG, Popper AN, Fay RR. Auditory prostheses: New horizons. 1st ed. New York: Springer Science \& Business Media;2011. p.305-39.

20) Looi V, McDermott H, McKay C, Hickson L. Music perception of cochlear implant users compared with that of hearing aid users. Ear Hear 2008;29(3):421-34.

21) Looi V, McDermott H, McKay C, Hickson L. The effect of cochlear implantation on music perception by adults with usable pre-operative acoustic hearing. Int J Audiol 2008;47(5):257-68.

22) Galvin JJ 3rd, Fu QJ, Nogaki G. Melodic contour identification by cochlear implant listeners. Ear Hear 2007;28(3):302-19.
23) El Fata F, James CJ, Laborde ML, Fraysse B. How much residual hearing is 'useful' for music perception with cochlear implants? Audiol Neurootol 2009;14 Suppl 1:14-21.

24) Vongpaisal T, Trehub SE, Schellenberg EG. Identification of TV tunes by children with cochlear implants. Music Percept 2009;27(1): $17-24$.

25) Xu L, Zhou N, Chen X, Li Y, Schultz HM, Zhao X, et al. Vocal singing by prelingually-deafened children with cochlear implants. Hear Res 2009;255(1-2):129-34.

26) Franks JR. Judgments of hearing aid processed music. Ear Hear 1982; 3(1):18-23.

27) Gfeller K, Christ A, Knutson J, Witt S, Murray K, Tyler R. Musical backgrounds, listening habits, and aesthetic enjoyment of adult cochlear implant recipients. J Am Acad Audiol 2000;11(7):390-406.

28) Looi V, McDermott H, McKay C, Hickson L. Comparisons of quality ratings for music by cochlear implant and hearing aid users. Ear Hear 2007;28(2 Suppl):59S-61.

29) Sucher CM, McDermott HJ. Bimodal stimulation: benefits for music perception and sound quality. Cochlear Implants Int 2009;10 Suppl 1:96-9.

30) Chen JK, Chuang AY, McMahon C, Hsieh JC, Tung TH, Li LP. Music training improves pitch perception in prelingually deafened children with cochlear implants. Pediatrics 2010;125(4):e793-800.

31) Looi V, King J, Rebecca Kelly-Campbell R. A music appreciation training program developed for clinical application with cochlear implant recipients and hearing aid users. Semin Hear 2012;33(4): 361-80.

32) Gfeller K, Witt S, Adamek M, Mehr M, Rogers J, Stordahl J, et al. Effects of training on timbre recognition and appraisal by postlingually deafened cochlear implant recipients. J Am Acad Audiol 2002;13(3): $132-45$.

33) Jung KH, Cho YS, Cho JK, Park GY, Kim EY, Hong SH, et al. Clinical assessment of music perception in Korean cochlear implant listeners. Acta Otolaryngol 2010;130(6):716-23.

34) Choi WJ, Oh SH, Bahang J. Efficacy of music training on speech recognition and working memory in children wearing cochlear implants. Audiol Speech Res 2017;13(1):70-7. 


\section{정답 및 해설}

답 (3)

해 설 중이결핵은 매우 드문 질환으로 알려져 있으며 이전의 보고에 따르면 만성 중이염에서 중이결핵이 차지하는 비율은 1946년 $1.9 \%$ 에서 1973년 Palva 등은 0.9\%, 1983년 Jeang 등은 0.04\% 정도로 보고하고 있다. 중이결핵의 감염경로로는 폐결핵이 있는 경우 가래에 존재하는 결핵균의 이관을 통한 직접적인 전파, 타장기의 결핵이 있는 경우 감염병소로부터 혈행성으로 측두골에 전파 되거나, 화농성 중이염의 천공을 통한 전파경로들이 제시되고 있다. 임상양상은 초기에는 무통성 고막충혈, 팽륜, 이충만감, 고막천공과 삼출성 이루를 보이고 청력소실은 임상 소견보다 심한 것으로 되어 있으며 $90 \%$ 가 전음성이며 나머지 $10 \%$ 는 감각신경 및 혼합성 양상을 보이고 후기에 이르러서는 골파괴병변을 보이며 악취를 동반한 혈농성 이루 등이 흔하게 관찰된다. 중이결핵의 조직병리학적 소견으로는 중이 및 중이강 내 점막의 부종과 함께 건락성 괴사 및 Langhan's giant cells로 이루어진 육아종을 관찰할 수 있고 결핵성 육아조직 및 농성 삼출물로 채워지며, 중이, 유양돌기, 이소골의 파괴가 나타나게 된다. 진단은 이러한 특징적인 임상양상으로 추정할 수 있으나 본 증례와 같이 환자의 특징적인 병력을 결 코 간과해서는 안되며, 고막소견, 측두골방사선촬영, 흉부방사선 소견, 투베르쿨린 반응검사를 통해 임상적인 진단이 이루 어 질 수 있다. 그러나 결핵성 중이염 환자의 대다수가 대부분 수술 중 생검이나 수술 후 병리조직학적으로 진단이 이루어 진 점을 감안할 때 확진은 균도말검사 및 배양검사에서의 결핵균의 확인과 조직 생검에 의해서 이루어 질 수 있다.

참고문헌: A Case of Secondary Tuberculous Otitis Media Combined with Multidrug-Resistant Tuberculosis. SeungKyu Nam, Shi-Nae Park, Sang Won Yeo, and Kyoung Ho Park. Korean J Audiol 2009;13(2):179-182.

답 (2)

해 설 수술 중 발생하는 안면신경 손상은 매우 드물지만 귀수술의 두려운 합병증으로, 중이 수술 후 예측하지 못한 안면신경 마비 의 경우 처치가 매우 중요하다. 수술 중 사용한 국소마취제에 의한 마비는 대부분 2 시간 이내 효과가 감소하므로 이 기간동 안 관찰할 필요가 있으며, 마비가 지속되는 경우 충전물(packing)에 의해 한면신경관 결손 부위에 압박 가능성이 있으므로 일단 제거해야 한다. 불완전 마비가 발생한 경우 경미한 외상, 부종에 의하여 발생한 경우이므로 스테로이드를 사용하면서 경과를 관찰한다. 완전마비가 발생한 경우 안면신경을 수술 시 확인하지 못한 경우나 안면신경손상의 가능성이 있으며 가 능한 속히 재수술을 시행해야 한다.

유양동 수술에서 발생하는 안면신경마비는 수술 완료 이후에 인지되는 경우가 수술 도중에 확인되는 경우보다 많으며, 부분 마비는 신경이 절단되었을 때가 아니라 신경부종 또는 열손상이 원인이며, 스테로이드를 투여하며 보존적으로 치료하며 대 개 보존적 치료만으로 회복된다. 신경섬유 손상이 있으면 절단면을 접합시키는 단단문합술(end to end anastomosis)을 시 행하는 것이 가장 이상적이다. 단단문합술이 불간으한 경우 대이개신경 또는 비복신경을 이용하여 신경이식(nerve interposition graft)을 절단된 안면신경 사이에 시행한다.

참고문헌: 이종대. 안면신경 질환_안면신경 질환 $\mathrm{ln}$ :이비인후과학-이과. 3rd ed. 군자출판사;2018. p.938.

채성원, 이동희. 유양돌기절제술 $\ln :$ 이비인후과학-이과. $3 r d$ ed. 군자출판사;2018. p.487. 